\title{
PENERAPAN LEMBAR KERJA SISWA (LKS) TERHADAP PEMAHAMAN KONSEP BANGUN DATAR PADA SISWA KELAS II SDN 7 KEBEBU
}

\author{
Wahyu Eka Sari ${ }^{1}$, Waridah ${ }^{2}$, Sukardi $^{3}$ \\ ${ }^{1}$ Mahasiswa Program Studi PGSD \\ ${ }^{2}$ Dosen STKIP Melawi
}

Jl. RSUD Melawi km. 04 Kec. Nanga Pinoh Kab. Melawi Kalimantan Barat ewahyu665@gmail.com, iedhachisulung@yahoo.com, pakardi83@gmail.com

\begin{abstract}
The purpose of this research to determine differences in understanding two-dimensional geometry concepts of students before and after application of worksheet in second grade students of SDN 7 Kebebu. This research is an pre-experimental research and used one group pretest-posttest design. Data collection techniques used essay tests. The Worksheet and instrument is validated by two experts namelly material expert and linguists used content validity. To determine reliability instrument data was analyzed used Cronbach Alpha formula, liliefors test for normality of data and test to determine differences in understanding two-dimensional geometry concepts before and after used worksheet. The result of calculation used the $t$ test showed that the sig value of $0,000<0,05$ so that $\mathrm{H}_{\mathrm{a}}$ is received. It can be conclude that there are significant difference in understanding two-dimensional geometry concept between before and after application of worksheet in second grade students of Elementary School 7 Kebebu.
\end{abstract}

Keywords: worksheet, understanding two-dimensional geometry concept

\begin{abstract}
Abstrak: Penelitian ini bertujuan untuk mengetahui perbedaan pemahaman konsep bangun datar siswa sebelum dan sesudah penerapan Lembar Kerja Siswa (LKS). Penelitian ini merupakan penelitian pre-eksperimen dan menggunakan desain one group pretest-posttest. Teknik pengumpulan data menggunakan tes tertulis esai. Lembar kerja siswa (LKS) dan instrumen penelitian divalidasi oleh dua ahli yaitu ahli materi dan ahli bahasa menggunakan validitas isi. Untuk mengetahui reliabilitas instrumen data dianalisis dengan menggunakan rumus Alpha Cronbach, uji liliefors untuk kenormalan suatu data dan uji-t untuk mengetahui perbedaan pemahaman konsep bangun datar sebelum dan sesudah menggunakan lembar kerja siswa (LKS). Hasil perhitungan menggunakan uji-t menunjukkan bahwa nilai sig $0,000<0,05$ sehingga $\mathrm{H}_{\mathrm{a}}$ diterima. Maka dapat disimpulkan bahwa terdapat perbedaan pemahaman konsep bangun datar yang signifikan antara sebelum dan sesudah penerapan lembar kerja siswa (LKS) di kelas II Sekolah Dasar Negeri 7 Kebebu.

Kata Kunci: Lembar kerja siswa (LKS), pemahaman konsep bangun datar
\end{abstract}


$\mathrm{P}$

emahaman konsep matematika merupakan salah satu hal yang terpenting dalam pembelajaran. Pemahaman merupakan terjemahan dari istilah understanding yang diartikan sebagai penyerapan arti suatu materi yang dipelajari. Pemahaman terhadap konsep-konsep matematika merupakan dasar untuk belajar matematika secara bermakna. Menyadari pentingnya pemahaman konsep dalam pembelajaran matematika, maka pembelajaran tersebut perlu direncanakan sedemikian rupa sehingga pada akhir pembelajaran siswa dapat memahami konsep yang dipelajarinya.

Berdasarkan hasil observasi dan wawancara yang telah peneliti lakukan di SDN 7 Kebebu, dalam proses pembelajaran siswa kurang dalam memahami konsep bangun datar, diantaranya yaitu siswa belum mengenal bentuk-bentuk bangun datar secara keseluruhan, siswa belum bisa membedakan bentuk persegi dengan persegi panjang dan siswa belum bisa mengelompokkan mana yang termasuk bangun datar persegi dan bangun datar persegi panjang, kurang tepat dalam menyebut bangun datar lingkaran dengan sebutan "bulat" serta siswa belum mengetahui titik sudut pada bangun datar. Selain itu siswa lebih asik mengobrol dengan temannya, keluar masuk kelas dengan alasan buang air kecil dan ketika diberi pertanyaan siswa terlihat bingung untuk memberikan jawaban. Pembelajaran yang berlangsung menggunakan metode ceramah dan tidak dipahami oleh siswa kelas rendah khususnya pada materi bangun datar sederhana. Pembelajaran terfokus pada guru sehingga siswa kurang aktif dalam proses pembelajaran, belum adanya penerapan atau pendekatan pembelajaran yang variatif serta tidak digunakannya media pembelajaran pada saat belajar materi bangun datar sehingga menyebabkan siswa belum memahami konsep bangun datar secara keseluruhan.

Pembelajaran matematika di sekolah memerlukan adanya upaya guru untuk mengorganisasikan materi matematika agar dapat memudahkan peserta didik menjalani proses belajar dan membuat peserta didik aktif serta dapat menemukan sendiri konsep materi matematika. Upaya pengorganisasian materi matematika tersebut dapat direalisasikan dalam pembelajaran matematika melalui e - I S S N : $2579-3993$ 
penggunaan bahan ajar berupa LKS yang disusun sesuai dengan perkembangan peserta didik. Oleh karena itu sudah seharusnya guru matematika merancang LKS yang dapat membimbing siswa menemukan konsep materi matematika yang dipelajarinya.

Majid (2013: 176) mengtakan bahwa lembar kerja siswa (Student Work Sheet) adalah lembar-lembaran berisi tugas yang harus dikerjakan oleh peserta didik. Lembar kerja biasanya berupa petunjuk, langkah-langkah untuk menyelesaikan suatu tugas. Suatu tugas yang diperintahkan dalam lembar kerja harus jelas kompetensi dasar yang akan dicapainya. Struktur LKS yang telah ditetapkan oleh Depdiknas, (dalam Octavia, 2016:13) terdiri dari beberapa komponen, yaitu: (1) Judul; (2) Petunjuk belajar; (3) Kompetensi yang akan dicapai; (4) Informasi pendukung; dan (5) Tugastugas, dan langkah-langkah kerja.

Lembar kerja siswa dikatakan berkualitas baik bila memenuhi syarat, Darmodjo dan Kaligis, (dalam Salirawati, 2006: 2) sebagai berikut: (1) Syarat didaktik; (2) Syarat konstruksi; dan (3) Syarat teknis. Selain itu, Darmodjo dan Kaligis, (dalam Salirawati, 2006: 2) menyatakan bahwa LKS juga memiliki beberapa manfaat sebagai berikut : (1) Memudahkan guru dalam mengelola proses belajar, misalnya mengubah kondisi belajar dari suasana "guru sentris" menjadi "siswa sentris"; (2) Membantu guru mengarahkan siswanya untuk dapat menemukan konsep-konsep melalui aktivitasnya sendiri atau dalam kelompok kerja; (3) Dapat digunakan untuk mengembangkan keterampilan proses, mengembangkan sikap ilmiah serta membangkitkan minat siswa terhadap alam sekitarnya; (4) Memudahkan guru memantau keberhasilan siswa untuk mencapai sasaran belajar.

Pemahaman konsep terdiri dari dua kata yaitu pemahaman dan konsep. Menurut Carin dan Sund (dalam Puspa Sari, 2017: 27) pemahaman merupakan kemampuan untuk menerangkan dan menginterpretasikan sesuatu, yang berarti bahwa seseorang telah memahami sesuatu atau telah memperoleh pemahaman. Konsep menurut Wardhani (dalam Kusumawati, 2017: 6) adalah ide abstrak yang dapat digunakan atau memungkinkan seseorang untuk mengelompokkan atau menggolongkan sesuatu objek. Menurut Duffin \& Simpson, (dalam 
Kesumawati, 2008: 230) pemahaman konsep diartikan sebagai kemampuan siswa untuk: (1) Menjelaskan konsep, dapat diartikan siswa mampu untuk mengungkapkan kembali apa yang telah dikomunikasikan kepadanya; (2) menggunakan konsep pada berbagai situasi yang berbeda; mengembangkan beberapa akibat dari adanya suatu konsep, dapat diartikan bahwa siswa paham terhadap suatu konsep akibatnya siswa mempuyai kemampuan untuk menyelesaikan setiap masalah dengan benar.

Masalah utama dalam penelitian ini adalah apakah terdapat perbedaan pemahaman konsep bangun datar yang signifikan antar sebelum dan sesudah penerapan lembar kerja siswa (LKS) pada siswa kelas II SDN 7 Kebebu. Adapun yang menjadi tujuan penelitian ini adalah untuk mengetahui apakah terdapat perbedaan pemahaman konsep yang signifikan sebelum dan sesudah penerapan LKS.

\section{METODE PENELITIAN}

Jenis penelitian yang digunakan dalam penelitian ini adalah penelitian eksperimen. Desain yang digunakan adalah one group pretest-posttest yaitu eksperimen yang dilaksanakan dalam satu kelompok saja tanpa kelompok pembanding. Subjek dalam penelitian ini adalah 17 siswa kelas II SDN 7 Kebebu tahun ajaran 2018/2019 yang terdiri dari 7 orang siswa perempuan dan 10 orang siswa laki-laki. Adapun yang menjadi objek dalam penelitian ini adalah pemahaman konsep bangun datar siswa kelas II SDN 7 Kebebu. Variabel bebas dalam penelitian ini adalah LKS siswa kelas II SDN 7 Kebebu. Sedangkan Variabel terikat dalam penelitian ini adalah pemahaman konsep bangun datar.

Teknik Penumpulan data yang digunakan dalam penelitian ini adalah tes tertulis bentuk esai. Jakni (2016: 155) mengatakan bahwa tes merupakan salah satu alat pengumpulan data dalam penelitian yang digunakan untuk mengetahui aspek kognitif siswa setelah mempelajari sesuatu materi pelajaran. Tes dilakukan untuk mengukur pemahaman konsep bangun datar siswa. Instrumen yang digunakan dalam penelitian ini adalah lembar tes tertulis bentuk esai. Lembar tes bentuk esai digunakan pada saat peneliti melakukan penelitian. Prosedur pengisian soal terlebih dahulu guru membacakan setiap soal kemudian siswa harus menuliskan jawaban pada titik-titik yang telah disediakan. 
Instrumen yang digunakan harus divalidasi terlebih dahulu. Validitas instrumen diartikan sebagai derajat kedekatan hasil pengukuran dengan keadaan sebenarnya (kebenaran), bukan masalah sama sekali benar atau seluruhnya salah, (Jakni, 2016:152). Untuk menentukan kevalidan peneliti menggunakan validitas isi. Arikunto (2013:81) mengatakan bahwa validitas isi bagi sebuah instrumen menunjuk suatu kondisi sebuah instrumen yang disusun berdasarkan isi materi pelajaran yang dievaluasi. Validitas isi dilakukan dengan membandingkan antara isi instrumen dengan materi pelajaran yang telah ditetapkan, Sugiyono (2016:353). Pengujian validitas isi dapat dibantu dengan menggunakan kisi-kisi instrumen.

Instrumen yang reliabel adalah instrumen yang bila digunakan beberapa kali untuk mengukur obyek yang sama, akan menghasilkan data yang sama, Sugiyono (2014: 121). Reliabilitas soal merupakan ukuran yang menyatakan tingkat keajegan atau kekonsistenan suatu soal tes, Jakni (2016:165). Untuk mengukur tingkat reliabilitas soal ini digunakan perhitungan rumus Alpha. Data yang diperoleh pada penelitian ini adalah data dari skor pemahaman konsep bangun datar siswa sebelum dan sesudah perlakuan. Untuk mengetahui data berdistribusi normal atau tidak, pada penelitian ini akan menggunakan uji Liliefors dengan SPSS, yang mana uji ini dilakukan pada data tunggal. untuk menguji hipotesis komparatif dua sampel yang berkorelasi digunakan uji-t dengan bantuan SPSS 17.0.

\section{HASIL DAN PEMBAHASAN}

Penelitian ini dilaksanakan di kelas II SDN 7 Kebebu pada hari Selasa, 28 Agustus 2018 hingga 04 September 2018. Penelitian ini dilaksanakan sebanyak enam kali pertemuan. Pada pertemuan pertama peneliti memberikan pretest, pertemuan kedua hingga pertemuan kelima peneliti memberikan treatment, dan pertemuan keenam peneliti memberikan posttest. Sebelum melakukan penelitian, peneliti terlebih dahulu menyiapkan lembar kerja siswa (LKS) yang akan diterapkan dalam pembelajaran serta menyiapkan instrumen soal esai dan melakukan konsultasi dengan dosen pembimbing, Ibu Waridah, M.Pd. Penyusunan LKS disesuaikan dengan kompetensi dasar dan materi bangun datar sederhana di kelas II Sekolah Dasar. Penyusunan LKS disesuaikan dengan kompetensi 
dasar dan materi bangun datar sederhana di kelas II Sekolah Dasar.

\section{Hasil Uji Validitas}

Hasil uji validitas terhadap LKS setelah revisi oleh ahli materi memperoleh skor sebesar 60 dengan kategori baik dan LKS layak digunakan dengan revisi sedikit. Hasil uji validitas terhadap LKS setelah revisi oleh ahli bahasa memperoleh skor sebesar 45 dengan kategori sangat baik dan LKS layak digunakan.

Hasil uji validitas teradap instrumen penenelitian oleh ahli materi memperoleh skor sebesar 48 dengan kategori baik. Hasil uji validitas oleh ahli bahasa memperoleh skor sebesar 33 dengan kategori sangat baik. Dari hasil validitas dari dua orang validator tersebut menyatakan bahwa instrumen layak digunakan dalam penelitian.

\section{Hasil Uji Reliabilitas}

Uji reliabilitas instrumen soal esai menggunakan rumus Alpha. Berdasarkan hasil uji coba soal esai pada data pretest dapat diketahui bahwa $r_{\text {hitung }}>r_{\text {tabel }}$ atau $0,658>0,497$ maka soal dinyatakan reliabel. Pada data posttest dapat diketahui bahwa $\mathrm{r}_{\text {hitung }}>\mathrm{r}_{\text {tabel }}$ atau 0,564 $>0,497$ maka soal juga dinyatakan reliabel.
Sebelum menerapkan lembar kerja siswa (LKS) terlebih dahulu peneliti memberikan pretest pada siswa kelas II SDN 7 Kebebu dan setelah menerapkan LKS peneliti kemudian memberikan posttest pada siswa. Untuk mengetahui rata-rata nilai pretest dan posttest, nilai tertinggi dan nilai terendah siswa, peneliti menggunakan bantuan aplikasi SPSS 17.0 Berdasarkan data yang diperoleh bahwa nilai rata-rata siswa setelah penerapan LKS mengenai pemahaman konsep bangun datar lebih tinggi yaitu sebesar 78,53 dibandingkan sebelum penerapan LKS yaitu sebesar 54,41. Kemudian pada hasil pretest nilai terendah yang diperoleh siswa adalah 30 dan nilai tertinggi adalah 85, sedangkan pada hasil posttest nilai terendah yang diperoleh siswa adalah 60 dan nilai tertinggi adalah 100 . Secara umum ada perbedaan nilai ratarata antara sebelum dan sesudah penerapan LKS.

\section{Hasil Uji Normalitas}

Untuk menguji kenormalan suatu data dalam penelitian ini, peneliti menggunakan uji liliefors dengan SPSS. Dalam uji ini data dikatakan berdistribusi normal jika nilai sig > 0,05. Untuk mengetahui hasil perhitungan liliefors, dapat dilihat nilai 
sig pada kolom Kolmogorov-Smirnov ${ }^{a}$, karena pada catatan kaki yang berada di bawah tabel menyatakan bahwa liliefors Significance Correction yang berarti penyesuaian liliefors. Dari output dapat diketahui bahwa nilai sig untuk pretest adalah 0,111. Karena dari hasil perhitungan SPSS tersebut $0,111>0,05$ maka data tersebut berdistribusi normal. Kemudian untuk data posttest diketahui nilai sig adalah 0,200. Karena dari hasil perhitungan SPSS tersebut 0,200>0,05 maka data tersebut berdistribusi normal.

\section{Hasil Uji Hipotesis}

Uji-t digunakan untuk mengetahui apakah terdapat perbedaan pemahaman konsep bangun datar yang signifikan antara sebelum dan sesudah penerapan LKS. Tabel di bawah ini menunjukkan hasil perhitungan uji-t menggunakan bantuan aplikasi SPSS 17.0 .

Hasil analisis menunjukkan bahwa ada perbedaan pemahaman konsep bangun datar yang signifikan antara sebelum dan sesudah penerapan LKS. Hal itu dapat dilihat dari output bahwa sig. (2-tailed) 0,000. Karena dari hasil perhitungan SPSS tersebut $0,000<0,05$ maka $\mathrm{H}_{\mathrm{a}}$ diterima dan $\mathrm{H}_{0}$ ditolak. Jadi dapat disimpulkan bahwa terdapat perbedaan pemahaman konsep bangun datar yang signifikan antara sebelum dan sesudah penerapan LKS.

\section{PEMBAHASAN}

Berdasarkan hasil pengolahan data sebelumnya diperoleh rata-rata hasil tes pemahaman konsep bangun datar sebelum diterapkan LKS adalah sebesar 54,41 dan rata-rata hasil tes pemahaman konsep bangun datar setelah diterapkan LKS adalah sebesar 78,53 . Perubahan nilai rata-rata pretest dan posttest tersebut menunjukkan adanya perbedaan dan peningkatan antara sebelum dan sesudah diterapkannya LKS.

Pada pertemuan pertama peneliti melakukan pretest terhadap 17 siswa kelas II SDN 7 Kebebu menggunakan lembar soal tes esai yang telah disiapkan. Untuk memudahkan siswa menjawab soal, peneliti terlebih dahulu membacakan soal, kemudian siswa menjawab pada titik-titik yang telah disediakan. Meskipun hal ini tidak mudah dilakukan, namun siswa terlihat sangat antusias ketika menerima lembar soal pretest. Hal ini dikarenakan siswa sangat tertarik dengan lembar soal pretest yang dibagikan, soal dilengkapi dengan gambar-gambar bangun datar dengan 
berbagai warna dan pada setiap soal menyediakan titik-titik sebagai tempat siswa menjawab soal dengan leluasa.

Kemudian, pada pertemuan kedua peneliti mulai melakukan treatment di kelas II menggunakan lembar kerja siswa (LKS). Pada kegiatan eksplorasi guru membagikan LKS kepada seluruh siswa. Bagi siswa ini adalah hal yang tidak biasa mengingat sebelumnya mereka belum pernah menerima LKS seperti yang peneliti gunakan. Namun meskipun demikian, mereka terlihat lebih semangat untuk belajar. Di dalam LKS terdapat penjelasan singkat mengenai materi yang dipelajari beserta gambargambar yang penuh dengan warna dan keterangan-keterangan yang menunjukkan sisi dan titik sudut pada segitiga maupun lingkaran, sehingga siswa lebih mudah memahaminya.

Untuk pertemuan ketiga, keempat dan kelima peneliti melakukan hal yang sama dengan menerapkan LKS dalam pembelajaran, hanya saja materinya yang berbeda dan tetap merupakan materi lanjutan sebelumnya. Seluruh siswa sangat senang ketika menerima LKS saat proses pembelajaran berlangsung. Hal ini dikarenakan tampilan LKS yang menarik dan penuh dengan warna sesuai dengan syarat LKS menurut Darmodjo dan Kaligis (dalam Salirawati, 2006: 2) sehingga tidak menimbulkan kesan yang membosankan pada siswa. Antusias dari siswa tidak jarang menimbulkan keributan dalam kelas. Peneliti berusaha untuk meminimalkan suasana kelas yang kurang kondusif tersebut.

Selama empat kali melaksanakan treatment menggunakan LKS siswa lebih percaya diri untuk berbicara di depan kelas dan seringkali siswa berlomba untuk maju ke depan kelas, hal ini terjadi karena siswa lebih mudah dalam memahami materi dengan menggunakan LKS, sejalan dengan apa yang dinyatakan oleh Darmodjo dan Kaligis (dalam Salirawati, 2006: 2) yang menyatakan beberapa manfaat LKS diantaranya adalah membantu guru mengarahkan siswanya untuk dapat menemukan konsep-konsep melalui aktivitasnya sendiri dan memudahkan guru dalam mengubah kondisi belajar dari suasana "guru sentris" menjadi "siswa sentris". Selain itu hal tersebut juga sesuai dengan apa yang dikemukakan oleh Arsyad (dalam Afifah, 2015: 3) bahwa LKS yang digunakan sebagai media pembelajaran juga dapat memperjelas penyajian pesan dan informasi 
sehingga proses belajar semakin lancar dan meningkatkan hasil belajar.

Pertemuan keenam adalah pertemuan terakhir dalam pelaksanaan penelitian ini. Pada pertemuan ini peneliti memberikan posttest kepada seluruh siswa setelah empat kali menerima treatment. Dari hasil pretest dan posttest yang telah diperoleh kemudian peneliti melakukan analisis terhadap beberapa jawaban siswa. Pada hasil pretest pada indikator menyebutkan kembali mengenai konsep yang dipelajari menunjukkan bahwa secara umum masih banyak ditemukan siswa yang belum bisa menentukan nama bangun datar dengan benar dan siswa juga belum bisa menentukan sisi-sisi maupun menuliskan nama sisi bangun datar. Hasil jawaban pada soal dengan indikator memberikan contoh dari konsep yang dipelajari ternyata terdapat siswa yang tidak memberikan jawaban. Hal ini bisa saja terjadi karena siswa tersebut belum memahami konsep dari masing-masing bangun datar sehingga siswa sulit memberikan contoh benda yang berbentuk persegi ataupun persegi panjang.

Hasil jawaban pada soal dengan indikator mengklasifikasikan bentuk- bentuk bangun datar ditemukan bahwa siswa salah dan keliru dalam mengelompokkan benda yang berbentuk segitiga dan persegi. Kesalahan yang dilakukan siswa berupa pengelompokkan yang terbalik atau tertukar serta siswa tidak menjawab dengan lengkap. Dalam mengurutkan bangun datar siswa juga masih keliru. Dari hasil jawaban siswa hanya menuliskan urutan bangun datar sesuai denga soal tanpa memperhatikan urutan ukuran bangun datar yang diminta dalam soal. Pada indikator terakhir yaitu menyajikan konsep dalam berbagai bentuk representasi matematis (gambar), hasil jawaban siswa menunjukkan bahwa siswa sudah bisa menggambarkan bentuk bangun datar yang diminta dalam soal, hanya saja siswa belum bisa memberikan nama setiap titik sudut bangun datar secara berurutan dan benar.

Kemudian setelah peneliti menerapkan lembar kerja siswa (LKS) saat proses pembelajaran, dapat dilihat pada hasil jawaban posttest siswa menunjukkan bahwa sebagian besar siswa sudah mampu memahami konsep bangun datar dengan baik. Siswa sudah bisa menentukan nama bangun datar, menentukan dan 
menuliskan setiap sisi dari bangun datar, memberikan contoh benda yang berbentuk bangun datar, menggambar bangun datar berserta nama setiap titik sudutnya dan sudah bisa mengurutkan bangun datar meskipun hal ini tidak terjadi pada seluruh siswa. Maka jelaslah bahwa LKS dapat diterapkan dalam pembelajaran materi bangun datar untuk mempermudah siswa dalam memahami konsep-konsep materi bangun datar.

Hasil dari pengujian hipotesis menunjukkan bahwa adanya perbedaan pemahaman konsep bangun datar yang signifikan antara sebelum dan sesudah penerapan lembar kerja siswa (LKS) yang ditunjukkan dengan nilai sig $0,000<0,05$. Rata-rata hasil pemahaman konsep bangun datar siswa setelah menggunakan LKS lebih baik jika dibandingkan dengan sebelum menggunakan LKS. Dari penelitian tersebut mendapatkan hasil yang sama dengan penelitian yang telah dilakukan oleh Poni Saltifa, Irawan dan Meira Parma Dewi bahwa hasil belajar kemampuan pemahaman konsep matematika siswa menggunakan LKS lebih baik

\section{DAFTAR PUSTAKA}

Afifah, R. N. 2015. Pengembangan Lembar Kerja Siswa (LKS) Ilmu dibandingkan hasil belajar kemampuan konsep matematika siswa tanpa menggunakan LKS. Selain itu hasil pada penelitian ini juga sama dengan hasil penelitian yang telah dilakukan oleh Eka Yuli Sari Asmawati bahwa pengembangan LKS dan model pembelajaran inquiri terbimbing sangat membantu dalam peningkatan keterampilan berpikir kritis dan penguasaan konsep fisika siswa, keterampilan berpikir kritis sangat diperlukan oleh siswa karena menjadi modal dasar untuk memahami berbagai hal, diantaranya memahami konsep dalam disiplin ilmu.

\section{SIMPULAN}

Berdasarkan hasil pengolahan data yang telah dilakukan peneliti, menggunakan uji-t dengan bantuan SPSS 17.0 diketahui nilai sig 0,000 < 0,05. Dengan demikian maka $\mathrm{H}_{\mathrm{a}}-$ diterima dan $\mathrm{H}_{0}$ ditolak. Sehingga dapat disimpulkan bahwa terdapat perbedaan pemahaman konsep bangun datar yang signifikan antara sebelum dan sesudah penerapan lembar kerja siswa (LKS) di kelas II $\operatorname{SDN} 7$ Kebebu.
Pengetahuan Alam Berbasis Metode Percobaan. Skripsi tidak 
diterbitkan. Yogyakarta:

Universitas PGRI Yogyakarta.

Jakni. 2016. Metodologi Penelitian

Eksperimen Bidang Pendidikan.

Bandung: Alfabeta.

Kesumawati, N. Pemahaman Konsep

Matematika

dalam

Pembelajaran

Matematika.

Seminar Nasional Matematika

dan Pendidikan Matematika 2008 .

Kusumawati, W. 2017. Upaya

Meningkatkan Kemampuan

Pemahaman Konsep Melalui

Model Pemelajaran Berbasis

Masalah dengan Strategi Student

Teams Achievement Division

(STAD) Siswa Kelas VIII E SMP

Muhammadiyah 1 Purwokerto.

Skripsi tidak diterbitkan.

Fakultas Keguruan dan Ilmu

pendidikan. Universitas

Muhammadiyah Purwokerto.
Majid, A. 2013. Perencanaan Pembelajaran: Mengembangkan Standar Kompetensi Guru. Bandung: Remaja Rosdakarya.

Salirawati, D. Penyusunan dan kegunaan LKS dalam Proses Pembelajaran. Yogyakarta: UNY 2006.

Sari, E. F. P. "Pengaruh Kemampuan Pemahaman Konsep Matematika Mahasiswa Melaui Metode Pembelajaran Learning Starts with a Question". Jurnal Musharafa. Vol. 6, No. 1, Januari 2017.

Sugiyono. 2014. Metode Penelitian Kuantitatif, Kualitatif dan $R \& D$. Bandung: Alfabeta.

Sugiyono. 2016. Statistika untuk Penelitian. Bandung: Alfabeta. 